Vol. 6, n² | 2002

Varia

\title{
L. Perry Curtis, Jr., Jack the Ripper and the London Press
}

New Haven Ct. and London, Yale University Press, 2001, 354 pp., ISBN

0-300-008872-8.

\section{Clive Emsley}

\section{(2) OpenEdition}

\section{Journals}

Electronic version

URL: https://journals.openedition.org/chs/446

DOI: $10.4000 /$ chs. 446

ISSN: 1663-4837

\section{Publisher}

Librairie Droz

\section{Printed version}

Date of publication: 1 December 2002

Number of pages: 144-145

ISBN: 2-600-00812-8

ISSN: 1422-0857

\section{Electronic reference}

Clive Emsley, "L. Perry Curtis, Jr., Jack the Ripper and the London Press", Crime, Histoire \& Sociétés /

Crime, History \& Societies [Online], Vol. 6, n² | 2002, Online since 28 April 2009, connection on 22

March 2022. URL: http://journals.openedition.org/chs/446 ; DOI: https://doi.org/10.4000/chs.446

This text was automatically generated on 22 March 2022.

(c) Droz 


\title{
L. Perry Curtis, Jr., Jack the Ripper and the London Press
}

\author{
New Haven Ct. and London, Yale University Press, 2001, 354 pp., ISBN \\ 0-300-008872-8.
}

\section{Clive Emsley}

\section{REFERENCES}

L. Perry Curtis, Jr., Jack the Ripper and the London Press, New Haven Ct. and London, Yale University Press, 2001, 354 pp., ISBN 0-300-008872-8.

1 The classic English detective/murder story always ends with what is now popularly referred to as 'closure'. The detective unmasks the murderer and explains to the bewildered other characters, as well as to the reader, how the deed was done and why it was done. Order is restored. The survivors, and the reader, can get on with their lives since everything is resolved. One of the most striking, if not the most striking thing about the Jack the Ripper story is that there has never been closure. No brilliant detective or astute forensic scientist ever identified the killer and saw him, or her, brought to justice. The people of Whitechapel, of the rest of London, and of the rest of the United Kingdom got on with their lives, but they remained, as we remain, ignorant about the who and the why. This is the starting point for L. Perry Curtis Jr.'s carefully research and thought provoking study of Jack the Ripper and the London press.

2 In the century since the Whitechapel murders of the autumn of 1888 dozens of ripperologists have produced studies 'identifying' the killer. Perry Curtis is no such ripperologist, and anyone seeking the identity of the killer will find no help here. What he or she will find, however, is something far more significant and, ultimately more important. What interests Curtis is how the murders were reported in the press and, to a lesser extent, how these reports were received. The book begins with a broad contextualising of the site of the murders, the poor east London district of Whitechapel. This is followed by a survey of how the Victorian press had developed by 
the end of the nineteenth century, and of how it revelled in reporting sensation and murder. The central portion of the book provides a detailed analysis of how fifteen different London newspapers reported each of the Ripper murders, proposed ways to catch the killer and laid the blame for failure. The final sections draw some interesting and important conclusions about how the reports further pushed back the limits of what could be written about in the press. After having been appallingly violated by the Ripper, the injuries inflicted on the victims' bodies were luridly described in newspapers for the most prurient of readers. The brevity of the final inquest, on the body of Mary Kelly who had been the most brutalised victim, may have been to limit the scale of sensation-horror journalism. It is interesting also that, overall, the sensationalist Pall Mall Gazette, edited by W.T. Stead, appears to have been among the more restrained in its reporting.

Curtis portrays the unsolved Ripper crimes as a basic, unfinished framework that contemporaries sought to fill in. In some instances this filling in became a detailed criticism of the police and the Home Office; the Metropolitan Police, and particularly its Commisioner, Sir Charles Warren, were already under attack because of the violent treatment of demonstrators on Bloody Sunday and because of Warren's militarization of the institution. In other instances the comment ranged much wider to become an analysis of what was wrong with Victorian society, drawing particular attention to the social and economic divisions between the east and west ends of London. Moreover, as Curtis makes clear, filling in the story did not end as the murders disappeared from the front pages. And even among the most respected social historians of recent years, Curtis suggests, feminist passion and commitment has led to some curious extrapolations from, and even some distortion of the verifiable facts. Curtis's own analysis is thoughtful, convincingly argued, and firmly rooted in a thorough contextualisation of the events and a meticulous reading of sources. It will not put an end to the speculation of who committed the murders and why, or to periodic 'final' identifications of the killer, but the book clearly demonstrates how a perceptive and dispassionate historian can provide a completely new and valuable perspective on an old, well-worked story.

\section{AUTHORS}

\section{CLIVE EMSLEY}

The Open University, c.emsley@open.ac.uk 